\title{
Betonarme bir okul binasinın 4 farklı hizlı değerlendirme metodu ile deprem performansının karşılaştırması
}

\author{
Barış ÖZKUL ${ }^{1 *}$, Ezgi GÜLGEÇ¹ \\ ${ }^{1}$ Balıkesir Üniversitesi Müh. Fak. İnşaat Müh. Böl., Çağlş kampüsü, Balıkesir. \\ Geliş Tarihi (Received Date): 14.05.2021 \\ Kabul Tarihi (Accepted Date): 13.09.2021
}

$\ddot{O} \mathbf{z}$

$\mathrm{Bu}$ çalışmada, daha önceden ayrıntılı deprem performansı araştırılarak belirlenmiş olan bir betonarme çerçeve tipi okul binasının, 4 farklı ve 1 revize hızl değerlendirme yöntemi kullanilarak deprem performansı incelenmiş, her bir yöntem ile elde edilen sonuçlar karşılaştırllarak metotların görece üstün ya da eksik olduğu yönleri belirlenmiştir. Ayrıca, binanın göreli kat ötelemeleri bilgisayar programı ile hesaplanmış ve P25 Yönteminin revizyonu olan P25 ÖZ-KA metodu ile de deprem performansı araştırılmuştır. Daha önceden yapılmış olan ayrintılı inceleme ile belirlenen nihai sonuç ve çalışma kapsamında yapılan hızlı değerlendirme metotlarının her birinden elde edilen sonuçlar; binanın deprem performans düzeyinin "yetersiz" olduğu şeklindedir. Yöntemler arasında karşılaştırma yapılırken; uygulama kolaylığı, uygulama süresi, güvenilirlik ve kullanılan parametre sayısı baz alınmıştır. Çalışma ile ülkemizde daha önce defalarca yaşadığımız felaketlerin bir benzerinin yeniden yaşanmaması için deprem olmadan önce binaların performansları hakkında bir fikir elde edilebilecek olan hızlı değerlendirme metotlarının önemi vurgulanmıştır.

Anahtar kelimeler: Deprem performansı, hızlı değerlendirme, betonarme yapılar.

\section{Earthquake performance comparison of a reinforced concrete school building based on four different quick evaluation methods}

\begin{abstract}
*Barış ÖZKUL, ozkul@balikesir.edu.tr, http://orcid.org/0000-0002-3039-3381

Ezgi GÜLGEÇ, ezgigulgec@gmail.com, http://orcid.org/0000-0001-7799-6406
\end{abstract}

In this study, the earthquake performance of a reinforced concrete-framed school building, previously investigated and identified in detail, was reviewed using four 
different quick evaluation methods and one revised method. The results obtained by each method were compared in order to determine superior or weaker aspects of the methods in relative terms. Additionally, the interstory drifts of the building were calculated using a computer program, and its earthquake performance was analyzed via the P25 ÖZ-KA method, a revision of the P25 method. The final results obtained through the previously performed detailed investigation, as well as the results found through each of the quick evaluation methods applied as part of the study, suggest that the earthquake performance level of the building is "inadequate". Ease of application, duration of application, reliability, and the number of parameters used were taken as a basis for the comparison between methods. This study emphasizes the importance of quick evaluation methods which serve to provide an insight into the performance of buildings in anticipation of an earthquake, thus preventing a disaster that has been experienced in Turkey several times over.

Keywords: Earthquake performance, quick evaluation, reinforced concrete buildings

\section{Giriş}

Sismik hareketlilik açısından oldukça aktif bir bölgede yer alması başta olmak üzere, bilgi ve eğitim düzeyindeki yetersizlikler, malzeme kalitesizliği ve daha birçok etken dolayısıyla, Türkiye tarihi depremler açısından son derece olumsuz bir tabloya sahiptir. Ülkenin hemen hemen her noktasında, depremlerden zarar görmüş, konutları yıkılmış, kendisi ya da bir yakını can ve mal kaybına uğramış vatandaşlarımız bulunmaktadır. Türkiye ve dünyanın birçok bölgesindeki araştırmacılar, yaşanan depremlerden çeşitli dersler çıkarmış, tecrübeler kazanmış ve depremlerin bir sonraki tekrarında oluşabilecek zararları azaltabilmek için yeni fikirler ortaya atmışlardır.

Elbette, depremler gerçekleştikten sonra ortaya çıkan zararların ortadan kaldırılmasına yönelik çalışmalar önemlidir ve bu konuda hazırlık yapılması gerekmektedir. Deprem gibi büyük bir yer hareketinin dolaylı olarak sebep olduğu afetin sonuçlarının ortadan kaldırılması için "Afet Yönetimi" adı verilen çalışmaların hızlı ve etkin şekilde yapılması elzemdir. Ancak, deprem olmadan önce alınması gereken ve "Risk Yönetimi” olarak ifade edilen çalışmaların yürütülmesi ve depremlerin bir sonraki tekrarında verebilecekleri muhtemel zararların önüne, deprem olmadan önce geçilmesi çok daha önemlidir[1]. Bu amaçla yürütülmesi gereken çalışmaların başında, binaların deprem sırasında gösterecekleri davranışın belirlenmesi ve yeterli dayanımı sergileyemeyecek nitelikte olanlarının önceden tespit edilerek kontrollü şekilde yık1lması ya da güçlendirilmesi gelmektedir.

Yapıların deprem sırasında sergileyecekleri davranışın deprem olmadan önce belirlenmeye çalışılmasının en önemli amacı; gerçekleşebilecek bir depremde yeterli dayanıma sahip olmayan yapıların deprem sırasında sergilemesi gereken performans seviyesine ulaşabilmeleri için uygulanacak güçlendirme sürecine karar verilmesi ya da kontrollü şekilde yıkılarak can kayıplarına sebep olmalarının engellenmesidir. Nüfus yoğunluğunun her geçen gün artış göstermesi, köyden kente göçün hızlanarak artmas1 gibi etkenler sebebiyle yapı stokundaki hızlı artış yap1 üretim sürecinde yanlış uygulamalara sebep olmuştur. Nitekim ülkemizde son 30 yılda gerçekleşen büyük depremler sonrasında da yapı stokunun ne kadar kötü durumda olduğu gözler önüne serilmiştir. Günümüze kadar süregelen bu kayıpların önüne geçilebilmesi için yapıların 
deprem performanslarının deprem olmadan önce belirlenmesi gerekmektedir ancak mevcut yapıların deprem performanslarının belirlenmesi oldukça karmaşık ve zor bir süreç olmakla birlikte ekonomik olarak da ciddi bir yük teşkil etmektedir. Kullanımdaki bir yapının detaylı şekilde incelenerek performans seviyesinin ortaya konulması ile ilgili sürecin halen kullanılmakta olan tüm yapılar için yürütülmesi ise neredeyse imkânsızdır. $\mathrm{Bu}$ süreci dikkate alarak, yapıların hızlı şekilde değerlendirilip risk seviyesine bağlı bir öncelik sırası oluşturulabilmesi amacıyla hızlı değerlendirme metotları geliştirilmiştir. Böylece, muhtemel büyük bir depremde yaşanabilecek can kayıplarının tamamının önüne geçilebilmesi teorik olarak mümkün hale gelebilmektedir. $\mathrm{Bu}$ yöntemlerin uygulanması ile mevcut yapı stokunun deprem performansı hızlı ve güvenilir bir şekilde kategorize edilebilmektedir. Hizlı değerlendirme metotlarının uygulanmasının en önemli amac1; bir ön değerlendirme yaparak binanın diğer binalara göre durumunun belirlenmesi ve can kaybına sebebiyet verebilecek nitelikte olan binaların karar süreçlerine öncelik verilmesidir. Hızlı değerlendirme metotları kesin sonuç ifade eden metotlar olmayıp risk seviyesine bağlı bir kategorizasyon yapılmasına olanak veren ilk aşama değerlendirme metotlarıdır.

Muhtemel bir depremde, göçme ihtimali daha yüksek olan riskli yapıları hızlıca belirleyerek oluşabilecek can ve mal kayıplarının önüne geçmek, Türkiye Cumhuriyeti gibi bu konuda tarihi boyunca çok büyük acılar yaşamış bir ülkenin en büyük sorumluluklarından biridir. Bu nedenle, ifade edilen amaca yönelik olarak binaların ön incelemesini yapacak inşaat mühendislerinin basit şekilde hâkim olabilecekleri, hızlı değerlendirme metotları geliştirilmiş ve bu metotlar çeşitli bölgelerde uygulanmıştır.

Kılıç [2] Balıkesir'de bulunan 50 adet betonarme binayı P25 Metodu kullanarak incelemiş, bunlardan birbirinden farklı özelliklerdeki 15 adet yapının TDY 2007'ye göre statik analizlerini yapmış ve P25 yönteminden elde ettiği sonuçlar ile karş1laştırmıştır. P25 Yönteminin genel olarak sağlıklı sonuçlar ortaya koyduğunu ancak yöntemde özellikle kiriş rijitlikleri, ağır çıkmalar ve çerçeve süreksizlikleri gibi faktörler ile ilgili bazı eksiklik ya da belirsizliklerin bulunduğunu ifade etmiştir.

Tural [3] 6 katlı betonarme bir yapının 4 farklı hızlı değerlendirme metodu ile deprem performansını incelenmiş, araştırmada uygulanan tüm yöntemlerin performans sonuçlarına göre binanın deprem güvenliğinin yeterli düzeyde olmadığını göstermiştir.

Özkaratay [4] 1999 Düzce depreminde yıkılan 6 katlı betonarme bir binanın 3 farklı hızlı değerlendirme metodu ile deprem performansını araştırmış ve bu metotları karşılaştırarak elde ettiği sonuçların birbirileriyle uyumlu ve gerçeğe yakın olduğunu ifade etmiştir. Ayrıca, incelediği binanın beton kalitesi ve etriye sıklığı parametrelerinin çalışmayı yaptığı günlerdeki yönetmelik şartlarına uygun şekilde inşa edilmiş olsaydı, binanın depremi "az hasar" alarak atlatabileceğini de ifade etmiştir.

Bütün [5] Manisa bölgesinde belirlediği 35 adet ve literatürde bulunan çalışmalardan seçtiği 6 adet betonarme binanın deprem performanslarını 4 farklı hızlı değerlendirme metodu uygulayarak incelemiş ve çalışma kapsamında geliştirdiği bir hızlı değerlendirme yöntemi ile elde ettiği tüm sonuçları karşılaştırılmıştır.

Kızıkkaya [6] 3 farklı bloktan oluşan bir ilkokul binasının 3 farklı hızlı değerlendirme metodu kullanarak deprem performansını karşılaştırmıştır. Yaptığı çalışmada, FEMA 154 ve Kanada Sismik Tarama Yöntemlerinin daha hızlı uygulanabileceğini ancak bu 
metotların güvenilirliklerinin nispeten daha düşük olduğunu ifade etmiş, Japon Sismik İndeks metodu uygulamasının daha uzun sürmesine karşılık daha güvenilir sonuçlar ortaya koyduğunu vurgulanmıştır. Yöntemlerin üstünlük ve yetersizliklerini de göz önünde bulundurularak, Kanada Sismik Tarama Yönteminin ülkemiz için en uygun yöntem olabileceğini ifade etmiştir.

Kaya [7] P25 metodu için, göreli kat ötelemelerini de dikkate alan bir revizyon önermiştir. P25 ÖZ-KA metodu olarak sunulan revizyon ile Balıkesir'deki 63 adet betonarme binanın deprem performansları incelenmiş, binalar "göçer" veya "göçmez" şeklinde sınıflandirılmış, P25 metodunda belirsiz (gri) alan olarak ifade edilen bölge revize metotta elde edilen göreli kat ötelemelerine bağlı olarak kaldırılarak orijinal metoda göre daha net bir sonuç ortaya konulmuştur.

Efekan [8] 1999 Marmara depreminden sonra, tamamen yıkılmış ve orta hasar almıș iki betonarme bina ile birlikte 2016 yılında inşa edilmiş bir başka betonarme binanın üç farklı hızlı değerlendirme metodu ile deprem performanslarını incelemiştir. Gerçekleştirdiği değerlendirmeler sonucunda yapılarda en kısa sürede en makul sonucun FEMA 154 yöntemi ile elde edildiğini ifade etmiştir.

Işık ve Kutanis [9] Bitlis'te bulunan 94 adet betonarme binanın hızlı değerlendirmesini P25 metodunu kullanarak yapmışlar, inceledikleri yapıların \%50'sinin göçme riski taşımadığı, \%46'sının daha ayrıntılı şekilde incelenmesinin gerektiği ve \%4'nün ise göçme riski altında olduğunu tespit etmişlerdir. Yaptıkları çalışmanın, Bitlis'in yerleşim alanlarının tamamında uygulanarak deprem riskinin azaltılması gerektiğini belirtmişlerdir.

Uğur vd. [10], Tekirdağ ili ve çevre ilçeler için hazırlanan riskli bina tespit raporlarını incelemişler, kentsel dönüşüm uygulamaları sırasında ortaya çıkan genel ve özel problemler hakkında çeşitli çözüm önerileri sunmuşlardır.

Işık vd. [11] olası bir depremde ortaya çıkabilecek muhtemel zararların minimum düzeye indirgenmesi için mevcut yapılar ile ilgili olarak bir veri tabanı oluşturulması amacıyla; Kanada sismik tarama yöntemini kullanarak, Muş ilinde bulunan 200 adet betonarme binanın risk değerlendirmesini yapmışlardır. Böylelikle, hızlı değerlendirme sonuçları ile deprem geçirmiş yapıların gerçek davranışı arasındaki tutarlılığı da ortaya koymaya çalışmışlar, inceledikleri binaların \%5'ini çok tehlikeli ve \%47'sini yüksek öncelikli olarak sınıflandırmışlardır.

Gürbüz ve Tekin [12] muhtemel bir depremde oluşabilecek hasar ve kayıp ihtimallerini tahmin etmek için bir metot geliştirmeye çalışmışlar, bu amaçla 11 farklı tipteki betonarme yapının doğrusal olmayan statik itme analizlerini yapmışlardır. Araştırmacılar tarafından, analiz sonuçlarına bağlı olarak her bina grubuna ait 4 farklı hasar ihtimalini gösteren "kırılganlık eğrileri" oluşturulmuştur. Elde edilen eğriler kullanılarak, ileride oluşabilecek muhtemel bir depremde, sundukları çalışmada incelenen bina gruplarına benzer özellikteki yapılarda oluşabilecek olası hasarların tahmin edilebileceğini göstermişlerdir.

Türkel ve Tekeli [13], betonarme konut tipi yapıların, beton basınç dayanımları, donatı akma dayanımları ve etriye sıklaştırması durumlarını birer değişken olarak dikkate alınarak, yapısal modelleme ve bilgisayar çözümlemelerine ihtiyaç olmaksızın risk 
değerlendirmesinin yapılabilmesi amacıyla 100 adet betonarme bina incelemiş̧lerdir. İncelenen binaların büyük çoğunluğunda düz yüzeyli donatı kullanıldığı, beton dayanımının düşük olduğu ve taşıyıcı elemanların mesnet bölgelerinde etriye sıklaştırmasının uygulanmadığını aktarmışlar, bu tür binalarda birden fazla kusurun aynı anda bulunması durumunda çok büyük olasılıkla binanın "Riskli bina" sınıfında tespit edilebileceğini ifade etmişlerdir. Ayrıca yapıları kat adedine göre sınıflandırarak beton dayanımı ve etriye aralığının risk tespitindeki etkinliğinin de önemli derecede artış gösterdiğini, kat adedi attıkça risk yüzdesinin de arttığını belirtmiş̧lerdir.

Kepenek vd. [14] Antalya'da meydana gelebilecek olası bir depremde temel afet riskini azaltmaya yönelik bir çalışma gerçekleştirmişlerdir. Türkiye'nin en kalabalık 5. şehri olan Antalya'yı iki ana bölge ve onların alt bölgelerine ayırarak 26610 adet 1 ila 7 kat arasındaki betonarme binayı görsel olarak incelemişler, belirledikleri alt bölgelerde ikinci düzey inceleme yaparak Antalya için bir sınır değer tespit etmişlerdir. Yapılan mikro bölgeleme çalışması ile sınır değerin altında kalan bölgeler öncelikli olarak incelenmesi gereken bölgeler olarak ifade edilmiştir.

Erşahan vd. [15] Kahramanmaraş'ta bulunan 342 adet betonarme binanın deprem performanslarını P25 yöntemini kullanarak araştırmışlar, 121 binayı düşük riskli, 121 binayı ayrıntılı olarak incelenmesi gereken ve 100 binayı da çok riskli olarak tespit etmişlerdir.

Hızlı değerlendirme metotları maliyet ve zaman kazanımı açısından oldukça avantajlı olmalarına karşılık elde edilen sonuçların güvenilirliği konusunda bazı belirsizlikler barındırmaktadırlar. Hızlı değerlendirme metotlarından bazıları tamamen görsel tespitler ve değerlendirmeyi yapan inşaat mühendisinin tecrübelerine dayalı olarak bir sonuç ortaya koyarken bazıları yapıya ait sayısal parametreleri dikkate alan hesaplamalar sonucunda yapı ile ilgili bir kanı ortaya koymaktadırlar.

\section{Yöntem}

Balıkesir Üniversitesi Meslek Yüksek Okulu D Blok binasının deprem performans analizleri, üniversitenin yetkili kurulları tarafından mühendislik hizmeti veren özel bir firmaya yaptırılmış ve binanın deprem güvenliğinin riskli olduğu tespit edilmiştir. $\mathrm{Bu}$ tespit sonrası bina boşaltılmış ve yıkılarak yeniden inşa edilmesi yönünde karar alınmıştır. Çalışma kapsamında, ayrıntılı deprem performansı daha önceden bilinen bu binanın 4 farklı hızlı değerlendirme yöntemi kullanılarak deprem performans sonuçları karşılaştırılmıştır. Çalışmada kullanılan hızlı değerlendirme metotlarından, FEMA 154; Amerika Birleşik Devletleri'nde geliştirilerek 2015 yılında revize edilmiştir[16]. Kanada Sismik Tarama Yöntemi; National Research Council Canada (NRCC) tarafından geliştirilmiştir[17]. Japon Sismik İndeks Yöntemi; The Japan Building Disaster Prevention Association (JBDPA) tarafından geliştirilmiş ve 2001 yılında revize edilmiştir[18]. P25 Hızlı değerlendirme yöntemi; Bal vd. [19] tarafından P5 Metodu adı ile geliştirilmiş, daha sonra aynı araştırmacılar tarafından P24 ve son olarak P25 olmak üzere iki versiyonu yayınlanmıştır[20]. Son olarak, Kaya [7] tarafından P25 hızlı değerlendirme yönteminin uygulaması sırasında dikkate alınmayan "Göreli Kat Ötelemeleri” de hesaba katılarak yöntem revize edilmiştir. 
Sunulan çalışma ile ayrıntılı deprem performansı bilinen yapının hızlı değerlendirme metotlarından elde edilen sonuçları karşılaştırılarak metotların görece üstün ya da eksik olduğu yönleri belirlenerek önceki araştırmacılar tarafından harcanan çabalara katkı verilmesi amaçlanmıştır. Yöntemler arasında karşılaştırma yapılırken; uygulama kolaylığı, uygulama süresi, güvenilirlik ve kullanılan parametre sayısı baz alınmıştır.

\section{Balıkesir'in depremselliği}

Sismik aktivitenin yoğun olarak yaşandığ 1 Balıkesir; Marmara ve Ege denizlerinin ikisine birden kıyısı olan, $12496 \mathrm{~km}^{2}$ yüz ölçüme sahip, ovalar arasında kurulmuş tarihi bir şehirdir. Balıkesir şehir merkezinin çevresinde büyük fay sistemlerinin bulunduğu bilinmektedir. Balıkesir'in güneyinde Ege grabeni ve kuzeyinde ise Kuzey Anadolu Fay sistemi şehrin sismik tehlike kaynaklarıdır[21].

29 Ocak 1898 tarihinde meydana gelen deprem, Balıkesir kent merkezini etkileyen en önemli deprem olarak tarihi kayıtlara geçmiştir. Deprem kayıtlarının 1900 yılından sonra alınmaya başlaması sebebiyle depremin büyüklüğü tam olarak bilinmemekle birlikte Balıkesir merkezindeki binaların çok büyük bölümünün bu depremde tamamen yıkıldığı bilinmektedir[22].

Şekil 1'de görüldüğü gibi, Balıkesir il sınırları içinde; Yenice-Gönen Fayı, Edremit Fay1, Balıkesir il merkezinden geçen Havran-Balıkesir Fay Zonu ve Balıkesir'in güneydeki Simav Fayı deprem üretme kapasitesi olan önemli sismik tehlike kaynaklardır[23].

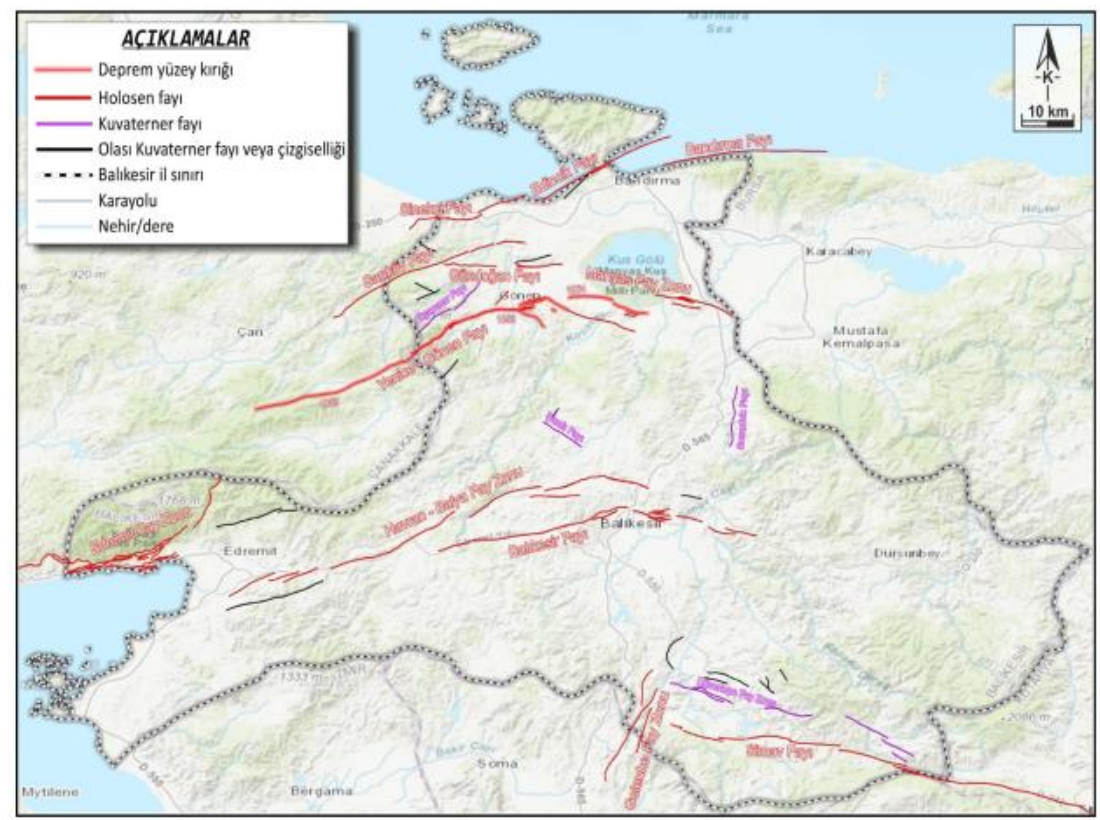

Şekil 1. Balıkesir diri fay haritası [23] 


\section{Balıkesir Üniversitesi Meslek Yüksekokulu D blok binası deprem performansı}

Balıkesir Üniversitesi tarafından yapının deprem performansının belirlenmesi için mühendislik hizmeti veren özel bir firma ile anlaşılmıştır. 1990'l1 yıllarda betonarme çerçeve şeklinde inşa edilen bina; Şekil 2'de görüldüğü gibi, bodrum, zemin ve 3 normal kattan oluşmaktadır ve kat yükseklikleri $3.80 \mathrm{~m}$ 'dir. $15 \mathrm{~cm}$ kalınlığında plak döşeme ile teşkil edilen yapı iki cephesinden bitişik nizamdır.

Mühendislik hizmeti alınan firma tarafından Balıkesir Üniversitesi, Meslek Yüksekokulu'nun deprem güvenliği performans analizleri, mod birleştirme yöntemi kullanılarak analizin yapıldığı gün yürürlükte olan TDY 2007 kurallarına göre yapılmıştır. Yapının teşkil edildiği alana üç adet zemin sondajı yapılmış ve zemin etüdü raporu hazırlanmıştır. Üniversite'nin yapı işleri daire başkanlığından elde edilen rapora göre; yapının üzerine teşkil edildiği zemin sınıfı Z3 (TA: 0,15,TB: 0,60), ve zemin grubu C'dir[24].

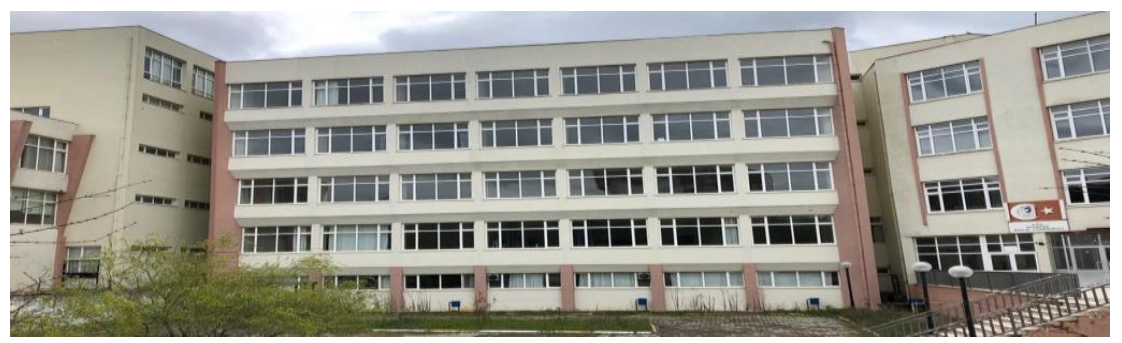

Şekil 2. Balıkesir Üniversitesi Meslek Yüksekokulu D blok ön cephe görünüşü

Yapıya ait kalıp planları, üniversitenin yapı işleri daire başkanlığından temin edilmiştir. P25 metodunda belirlenmesi gereken kritik kat olarak seçilen zemin kata ait kalıp planı ve yapı bilgisayar programı ile tanımlandıktan sonraki 3 boyutlu görünüşü Şekil 3 'te görülmektedir.
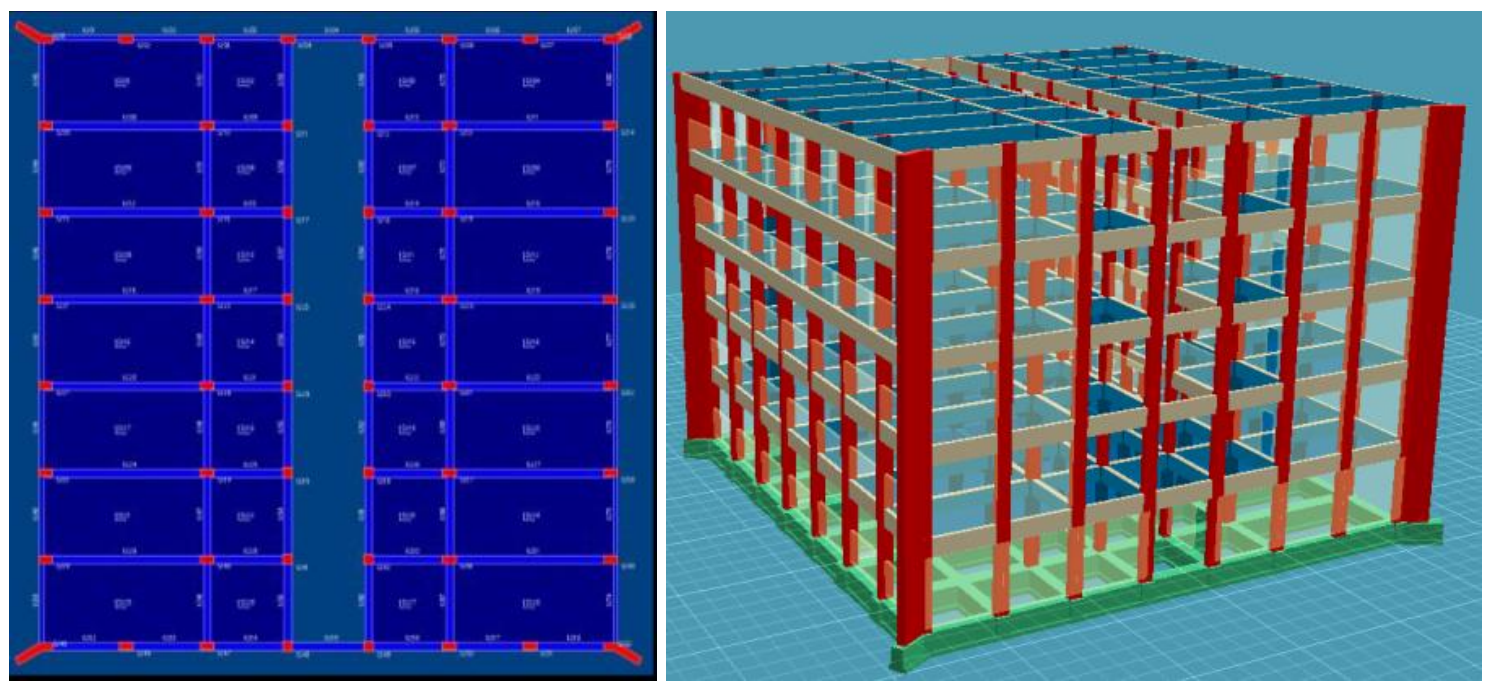

Şekil 3. Zemin kat kalıp planı ve yapının 3 boyutlu görünüşü. 


\subsection{Yaptya ait beton dayanımı ve donatı tespiti bilgileri}

Firma tarafından hazırlanan değerlendirme raporuna göre; birçok karot numune, alınırken parçalanmış, yerlerine yenileri alınmış ve karot değerleri oldukça düşük çıkmıştır. Binadan alınan karot numunelerine bağlı olarak beton dayanımı $4.6 \mathrm{Mpa}$ olarak belirlenmiştir. Yapının bodrum katında yüksek oranda nem olduğu ve yapının kolonlarına zarar verdiği tespit edilmiştir. Kolon ve kirişlerde donatı sınıfı, çapı, adedi ve yerleşimi belirlenmesi amacıyla pas payı sıyırmaları yapılmıştır. Şekil 4'te görüldüğü gibi; kolon donatılarının korozyona maruz kaldığı, düşey donatıların nervürlü, etriyelerinin ise $\Phi 8 / 25$ nervürsüz şekilde teşkil edilmiş olduğu ve uç bölgelerinde sıklaştırma yapılmadığ 1 tespit edilmiştir. Kirişlerde de nervürsüz donatılar kullanılmış olduğu ve etriye sıklaştırmalarının yapılmadığı tespit edilmiştir. Ayrıca, yapının 3. katında, koridor akslarında bulunan bazı kolon-kiriş birleşimlerinde rijit düğüm noktası oluşturulamadığı, tüm yapıda etriye kancalarının $90^{\circ}$ bükülmüş olduğu da belirtilmiştir.

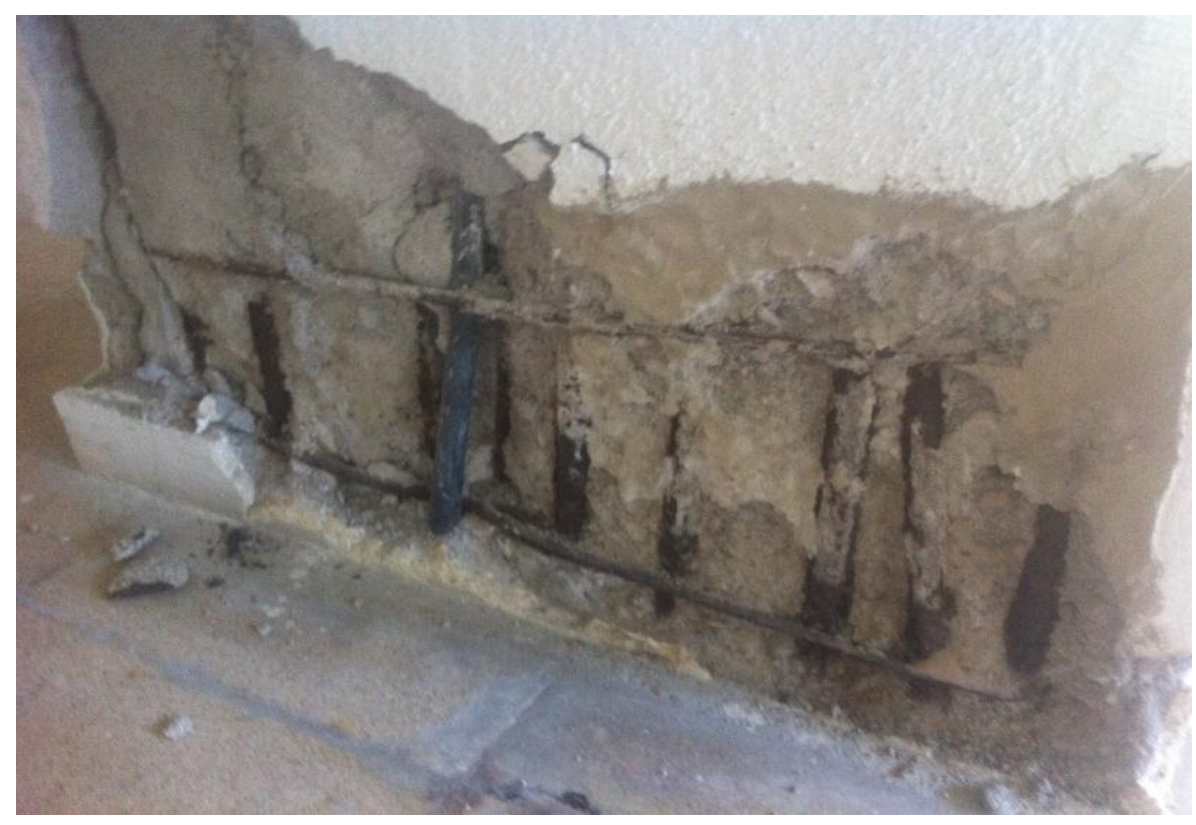

Şekil 4. Binanın kolonlardaki genel durum

Mühendislik hizmeti veren firma tarafından ayrıntılı deprem performans analizi yapılarak hazırlanan durum değerlendirme raporu sonucunda; binanın güçlendirilmesinin düşünülmesi durumunda, beton kalitesinin çok düşük olmas1 sebebiyle ankraj sırasında ciddi problemler yaşanılacağı, güçlendirme elemanlarının birlikte çalışmasının oldukça zor ve sonraki davranışın belirsiz olacağı ifade edilmiştir. Raporda, nihai görüş olarak yapının yıkılıp yeniden inşa edilmesi gerektiği belirtilmiştir[24].

\section{Yapının deprem performansının hızlı değerlendirme metotları ile belirlenmesi}

2017/070 kodlu BAP projesi [25] ile desteklenen ve Gülgeç [26(Ezgi)] tarafindan hazırlanan yüksek lisans tezi kapsamında incelenen yapının deprem performansı hızlı değerlendirme metotları kullanılarak araştırılmış, her bir yöntem ayrıntılı şekilde ele alınarak adım adım açıklanmıştır. Bu çalışmada, her bir metot ile ilgili genel bir 
değerlendirme yapılarak metotların kullandığı parametreler, sismik performans sonuçları ve karşılaştırma değerleri sunulmuştur.

\subsection{FEMA 154 sismik tarama yöntemi}

2015 yılında güncellenmiş son versiyonu bir el kitabı olarak yayınlanan FEMA 154 hızlı tarama yöntemi ile mevcut yapının deprem performansının en kısa sürede belirlenmesi amaçlanmaktadır. Deprem performansı araştırılan yapının bulunduğu ülkede FEMA Yöntemi kapsamında tanımlanan taşıyıcı sistem türlerinin ifade edildiği modern anlamdaki ilk yönetmelik yılı forma işlenmekte, sonuç puanı hesaplanırken yapının inşa yılına bağlı olarak bir değer belirlenmektedir. Bu tanıma göre, ülkemizde betonarme yapıların teşkili sırasında uygulanması gereken tasarım esaslarının modern anlamda ifade edildiği ilk yönetmelik 1949 yılı yönetmeliğidir. FEMA Yönteminde değerlendirme yılı olarak yönetmeliğin kapsamlı şekilde geliştirildiği yıl ifade edilmektedir. Buna bağlı olarak ülkemizde 1975 yılında yayınlanan "Afet Bölgelerinde Yapılacak Yapılar Hakkında Yönetmelik" değerlendirme yılı olarak kabul edilmiştir. Yöntem uygulanırken, deprem performansı araştırılan yapının bulunduğu bölgenin sismik aktivitesine bağlı olarak önceden oluşturulmuş beş farklı form kullanılmaktadır. Binanın taşıyıcı sistemine, yapı malzemesine ve yapının bulunduğu bölgenin sismik hareketliliğine bağlı olarak binaya ait temel yapısal risk puanı belirlenmektedir. İncelenen yapının düzensizliğinin olup olmadığı, zemin sınıfı ve cinsi ile yüksekliği gibi önemli parametreler baz alınarak formdan elde edilen değerler temel yapısal puanı ile toplanır veya çıkarılır. $\mathrm{Bu}$ şekilde binanın deprem etkisi altındaki davranışını tanımlayan "Son Yapısal Puanı" (S) elde edilir. Hesaplanan "S', puanı, "Kesim Değeri" olarak tanımlanan sayısal bir değer ile karşılaştırılır ve bu kesim değerinin altındaki yapılar "Güvensiz", kesim değerinin üstündeki yapılar ise "Güvenli" olarak nitelendirilmektedir. "S' puanı 2'den küçük olduğunda 'Güvensiz' olarak isimlendirilen yapıların ayrıntılı olarak incelemeye ihtiyacı olduğu kanısına varılmaktadır. Yani ' $S$ '" puanı büyüdükçe yapının deprem performansının iyi olduğunu ifade etmektedir[16].

Balıkesir ili, deprem tehlike haritasında en riskli bölgede bulunması sebebiyle, FEMA 154 yöntemi ile yapılan değerlendirmede, Şekil 5'te görüldüğü gibi çok yüksek sismik hareketlilik için hazırlanan veri toplama formu kullanılmıştır. Sonuç puanı, SL1=1.3 $<2$ olarak bulunmuş ve limit puanı 2'den küçük olması sebebiyle, yapı "Güvensiz" olarak belirlenmiştir.

\subsection{Kanada Sismik Tarama Yöntemi}

Kanada Ulusal Araştırma Birliği tarafından yayınlanan ilkeler doğrultusunda önerilen yöntem çok aşamalı ve detaylı bir incelemenin ilk aşaması olarak düşünülmekte ve incelenen yapı grubundaki her bir binanın deprem riskinin sayısal olarak ön değerlendirilmesini içermektedir[17]. Asıl değerlendirme öncesinde yapı hakkında bir fikir edinilmesi amacıyla geliştirilen bu yöntemin uygulanmasının ardından daha ayrıntılı bir değerlendirme yapılması gerekliliği vurgulanmaktadır.

Yöntemde kullanılan her bir değişkenin bir harf ile temsil edildiği bu yöntemde, yapının durumuna bağlı olarak her bir değişken için bir katsayı belirlenmektedir. Şekil 6. ve Şekil 7. de görülen iki form ile uygulanan yöntemde hesaba katılan parametreler ve sınır değerleri Tablo 1'de görüldüğü gibidir; 
Çok Yüksek Sismik Hareketlilik

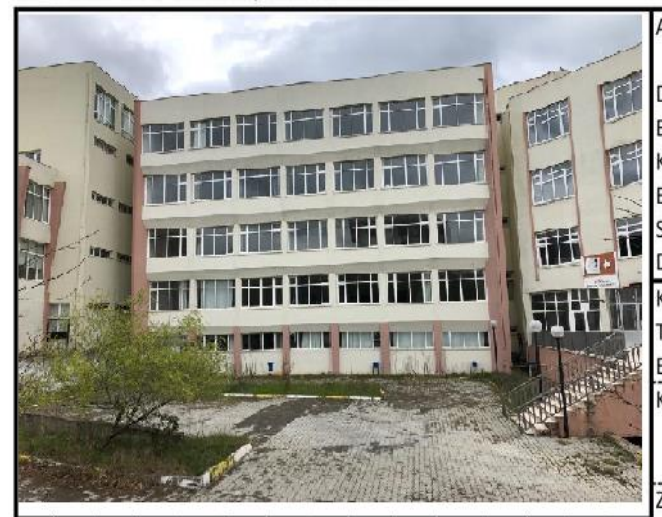

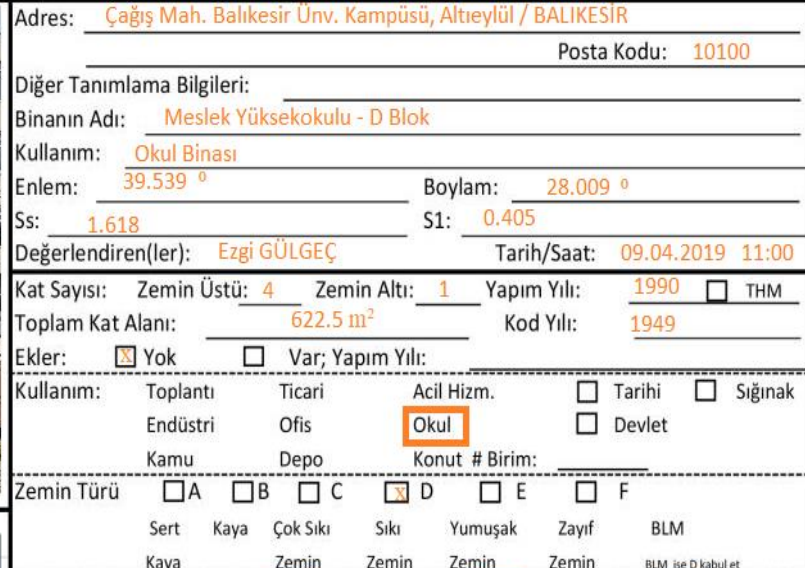

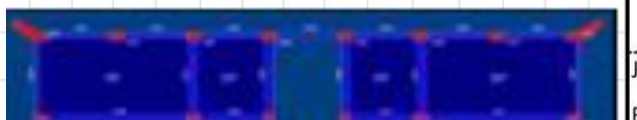

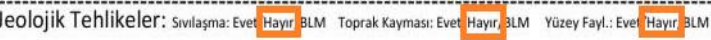

Bitişik Nizam: $\square$ Çekiçleme $\square$ Yan Binadan Düşme Tehlikesi Olan Eleman

Düzensizlik: $\square$ Düşey (tip/derece) Kısa Kolon

$\square$ Plan (tip)_Döșeme Süreksizlig̈i

Dış Tehlikeler: $\square$ Sabitlenmemiş Baca $\square$ Ağır Cephe Kaplamalar

$\begin{array}{ll}\square \text { Sabitlenmemiş Baca } & \square \text { Ağır Cephe Ka } \\ \square \text { Parapetler } & \square \text { Eklentiler }\end{array}$

$\square$ Diğer

YORUMLAR:

D blok, B ve E blokları arasında, bitișik nizam olarak inşa edilmiștir. B ve E blok

a içten geçiși bulunmaktadır. Yapının Bodrum katında bazı kolonlarda,

korozyon etkisi görülmüştür.

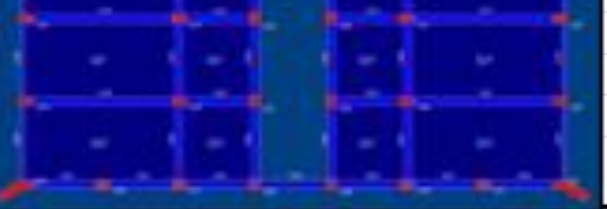

$\square$ Ayrı sayfada ek çizimler veya yorumlar

\begin{tabular}{|c|c|c|c|c|c|c|c|c|c|c|c|c|c|c|c|c|c|}
\hline \multicolumn{18}{|c|}{ TEMEL YAPISAL RISK PUANI, DEǦişTiRiciLER, SONUÇ PUAN SL1 } \\
\hline FEMA BINA TIPLERI & W1 & W1A & W2 & $\begin{array}{c}\text { S1 } \\
\text { (MRF) }\end{array}$ & $\begin{array}{c}\text { S2 } \\
\text { (BR) }\end{array}$ & $\begin{array}{c}\text { S3 } \\
\text { (LM) }\end{array}$ & $\begin{array}{c}\text { S4 } \\
\text { (RCSW) }\end{array}$ & $\begin{array}{c}\text { S5 } \\
\text { (URM } \\
\text { INF) } \\
\end{array}$ & $\begin{array}{c}\mathrm{C} 1 \\
\text { (MRF) }\end{array}$ & $\begin{array}{c}C 2 \\
\text { (SW) }\end{array}$ & $\begin{array}{c}\text { C3 } \\
\text { (URM } \\
\text { INF) }\end{array}$ & $\begin{array}{l}\text { PC1 } \\
\text { (TU) }\end{array}$ & PC2 & $\begin{array}{l}\text { RM1 } \\
\text { (FD) }\end{array}$ & $\begin{array}{l}\text { RM2 } \\
\text { (RD) }\end{array}$ & URM & MH \\
\hline Temel Puan & 2.1 & 1.9 & 1.8 & 1.5 & 1.4 & 1.6 & 1.4 & 1.2 & 1.0 & 1.2 & 0.9 & 1.1 & 1.0 & 1.1 & 1.1 & 0.9 & 1.1 \\
\hline Ciddi Düşeyde Düzensizilik, VL1 & -0.9 & -0.9 & -0.9 & -0.8 & -0.7 & -0.8 & -0.7 & -0.7 & -0.7 & -0.8 & -0.6 & -0.7 & -0.7 & -0.7 & -0.7 & -0.6 & NA \\
\hline Orta Derece Düşeyde Düzensizilik, VL1 & -0.6 & -0.5 & -0.5 & -0.4 & -0.4 & -0.5 & -0.4 & -0.3 & -0.4 & -0.4 & -0.3 & -0.4 & -0.4 & -0.4 & -0.4 & -0.3 & NA \\
\hline Planda Düzensizlik, PL1 & -0.7 & -0.7 & -0.6 & -0.5 & -0.5 & -0.6 & -0.4 & -0.4 & -0.4 & -0.5 & -0.3 & -0.5 & -0.4 & -0.4 & -0.4 & -0.3 & NA \\
\hline Kodlama Öncesi & -0.3 & -0.3 & -0.3 & -0.3 & -0.2 & -0.3 & -0.2 & -0.1 & -0.1 & -0.2 & 0.0 & -0.2 & -0.1 & -0.2 & -0.2 & 0.0 & 0.0 \\
\hline Değerlendirme Sonrası & 1.9 & 1.9 & 2.0 & 1.0 & 1.1 & 1.1 & 1.5 & NA & 1.4 & 1.7 & NA & -0.2 & 1.7 & 1.6 & 1.6 & NA & 0.5 \\
\hline Zemin Türü A veya B & 0.5 & 0.5 & 0.4 & 0.3 & 0.3 & 0.4 & 0.3 & 0.2 & 0.2 & 0.3 & 0.1 & 1.5 & 0.2 & 0.3 & 0.3 & 0.1 & 0.1 \\
\hline Zemin Türü $\mathrm{E}$ (1-3 kat) & 0.0 & -0.2 & -0.4 & -0.3 & -0.2 & -0.2 & -0.2 & -0.1 & -0.1 & -0.2 & 0.0 & 0.3 & -0.1 & -0.2 & -0.2 & 0.0 & -0.1 \\
\hline Zemin Türü E (>3 kat) & -0.4 & -0.4 & -0.4 & -0.3 & -0.3 & NA & -0.3 & -0.1 & -0.1 & -0.3 & -0.1 & NA & -0.1 & -0.2 & -0.2 & 0.0 & NA \\
\hline Minimum Puan SMiN & 0.7 & 0.7 & 0.7 & 0.5 & 0.5 & 0.5 & 0.5 & 0.5 & 0.3 & 0.3 & 0.3 & 0.2 & 0.2 & 0.3 & 0.3 & 0.2 & 1.0 \\
\hline
\end{tabular}

SONUÇ PUAN, SL1 $\geq$ SMIN $S L 1=1.3<2$

\begin{tabular}{|c|c|c|c|}
\hline \multicolumn{4}{|c|}{ INCELEMENIN KAPSAMI } \\
\hline $\begin{array}{l}\text { Dış: } \\
\text { iç: } \\
\text { Çizimler incelendi: } \\
\text { Zemin Türü Bilgisini } \\
\text { Jeolojik Tehlike Bilg } \\
\text { iletişime Geçilen Kiş }\end{array}$ & $\begin{array}{l}\square \text { Kısmi } \\
\square \text { Hiç } \\
\square \text { Evet } \\
\text { Kaynağı: } \\
\text { in Kaynağı: } \\
\end{array}$ & $\begin{array}{l}\square \text { Her Yönden } \\
\square \text { Görünür } \\
\square \text { Hayır } \\
\text { emin etüd rap } \\
\text { zemin etüd ra }\end{array}$ & $\begin{array}{l}\square \text { Havadan } \\
\square \text { Girildi } \\
\text { poru } \\
\text { poru }\end{array}$ \\
\hline \multicolumn{4}{|c|}{ IKINCI AŞAMA TARAMA YAPILDI MI? } \\
\hline $\begin{array}{l}\square \text { Evet, Level } 2 \\
\text { Yapısal Olmayan Te }\end{array}$ & ani, SL2 & et & $\begin{array}{l}\square_{\text {Hayır }} \\
\square \text { Hayır }\end{array}$ \\
\hline
\end{tabular}

DiĞER TEHLiKELER

Detaylı yapisal inceleme gerektiren tehlikeler var mı?

$\square$ Çekiçleme olasilı̈̆) (SL2) Limit puan olmadikça)

$\square$ Daha uzun olan bitişikteki binadan düşme tehlikesi olan elemanlar

$\square$ Jeolojik tehlike veya $\mathrm{F}$ zemin türü

Tașiyıcı sistemde kayda değer hasar/bozulma

\section{IŞLEM GEREKLi}

Detayl Yapısal inceleme Gerekli mi?

$\square$ Evet, bilinmeyen FEMA bina tipi veya diğer bina

Evet, puan limit puandan daha dūşük

Evet, diğer tehlikeler mevcut

Hayir

Detayı Yapısal Olmayan Inceleme Önerilir mi?

$\square$ Evet, değerlendirilmesi gereken yapısal olmayan tehlikeler saptandı Hayir, azaltulması gereken yapisal olmayan tehlikeler mevut fakat detaylı inceleme gerekli değil
Hayır, yapısal olmayan tehlike saptanmadı $\square$ BLM Bilgilerin doğrulanamadığı yerlerde yandaki ibareler işaretlenmelidir: THM= Tahmini veya güvenilir olmayan bilgi ya da BLM= Bilinmiyor $\begin{array}{lllll}\text { MRF: Moment taşivan çerçeve } & \text { RC: Betonarme } & \text { URM INF: Yĭgma duvar } & \text { MH: Prefabrik konut } & \text { FD: Esnek Diyafram } \\ \text { BR: Çeliik çaprazl çerçeve } & \text { SW: Perde duvar } & \text { TU: Panel duvar } & \text { LM: Hafif metal } & \text { RD: Rijid diyafram }\end{array}$

Şekil 5. Çok yüksek sismik hareketlilik bölgesi için FEMA 154 veri toplama formu 
Tablo 1. Kanada sismik tarama yöntemi parametre değerleri.

\begin{tabular}{|c|l|c|}
\hline Simge & \multicolumn{1}{|c|}{ Parametre } & Sinır değer \\
\hline A & Bölgenin sismik aktivite düzeyi & $1-4$ \\
\hline B & Zemin koşulları & $1-2$ \\
\hline C & Taşıyıcı sistem özellikleri & $1-3.5$ \\
\hline D & Düzensizlikler (her biri için bir değer alır ve toplanır) & $1-2$ \\
\hline E & Kullanım şekli & $0.7-3.0$ \\
\hline F & Yapısal olmayan tehlikeler & $1-6$ \\
\hline
\end{tabular}

Parametrelerin, Tablo 1'de görülen yapı özelliklerine bağlı olarak aldıkları değerler kullanılarak; yapısal indeks (SI), yapısal olmayan indeks (NSI) ve sismik öncelik indeksi değerleri (SPI) hesaplanmaktadır.

Yapısal indeks olarak ifade edilen SI;

SI = A.B.C.D.E.F

ifadesi ile hesaplanmaktadır.

Yöntemde yapısal olmayan indeks olarak ifade edilen NSI;

$\mathrm{NSI}=$ B.E.F

formülü ile hesaplanmaktadır.

Yapısal indeks ve yapısal olmayan indeks değerleri toplanarak sismik öncelik indeksi değeri, SPI hesaplanmaktadır;

$\mathrm{SPI}=\mathrm{SI}+\mathrm{NSI}$

Yukarıdaki denklemler kullanılarak elde edilen sonuçlar, Tablo 2'de görülen sınır değerler ile karşılaştırılarak binanın öncelik durumu belirlenmektedir.

Tablo 2. Kanada sismik indeks yöntemi sınır değerleri

\begin{tabular}{|c|c|c|}
\hline Sismik öncelik indeksi & Sınır değeri & Sonuç \\
\hline SPI & $>30$ & Çok Tehlikeli Yap1 \\
\hline SPI & $>20$ & Yüksek Öncelikli Yap1 \\
\hline SPI & $10-20$ & Orta Öncelikli Yap1 \\
\hline SPI & $<10$ & Düşük Öncelikli Yap1 \\
\hline
\end{tabular}

Kanada ulusal araştırma birliği tarafından yayınlanan kılavuza göre, puan türleri binanın yönetmelik yılı ve değerlendirme yılına bağlı olarak belirlenir. Yönetmelik yılı olarak tabir edilen, binanın tasarlanmasından önce yayınlanan son yönetmeliğin yürürlüğe giriş yılıdır. Değerlendirme yılı ise, kapsamlı değişikliklerin yapıldığ 1 ve detaylı deprem hesabı ilkelerinin sunulduğu yönetmelik yılıdır. Bu duruma göre; ülkemizde yayınlanan geçmiş yönetmelikler incelendiğinde, gerilme esaslı tasarımdan taşıma gücüne 
geçilmesi ve deprem hesabında tüm detayların açıklanması sebebiyle 1998 yılı değerlendirme yılı olarak belirlenmiştir. Deprem performansı araştırılan binanın 1990 yılında tasarlanmış olması sebebiyle yönetmelik yılı 1975 yönetmeliği olmaktadır.

Bu koşul ve parametrelere göre; yapısal indeks değeri SI=13.68, yapısal olmayan indeks değeri NSI=1.2 ve sismik öncelik indeksi değeri $\mathrm{SPI}=14.88$ olarak hesaplanmaktadır. Elde edilen SPI=14.88 değerine göre yapı "Orta Öncelikli Binalar" sınıfında yer almaktadır.

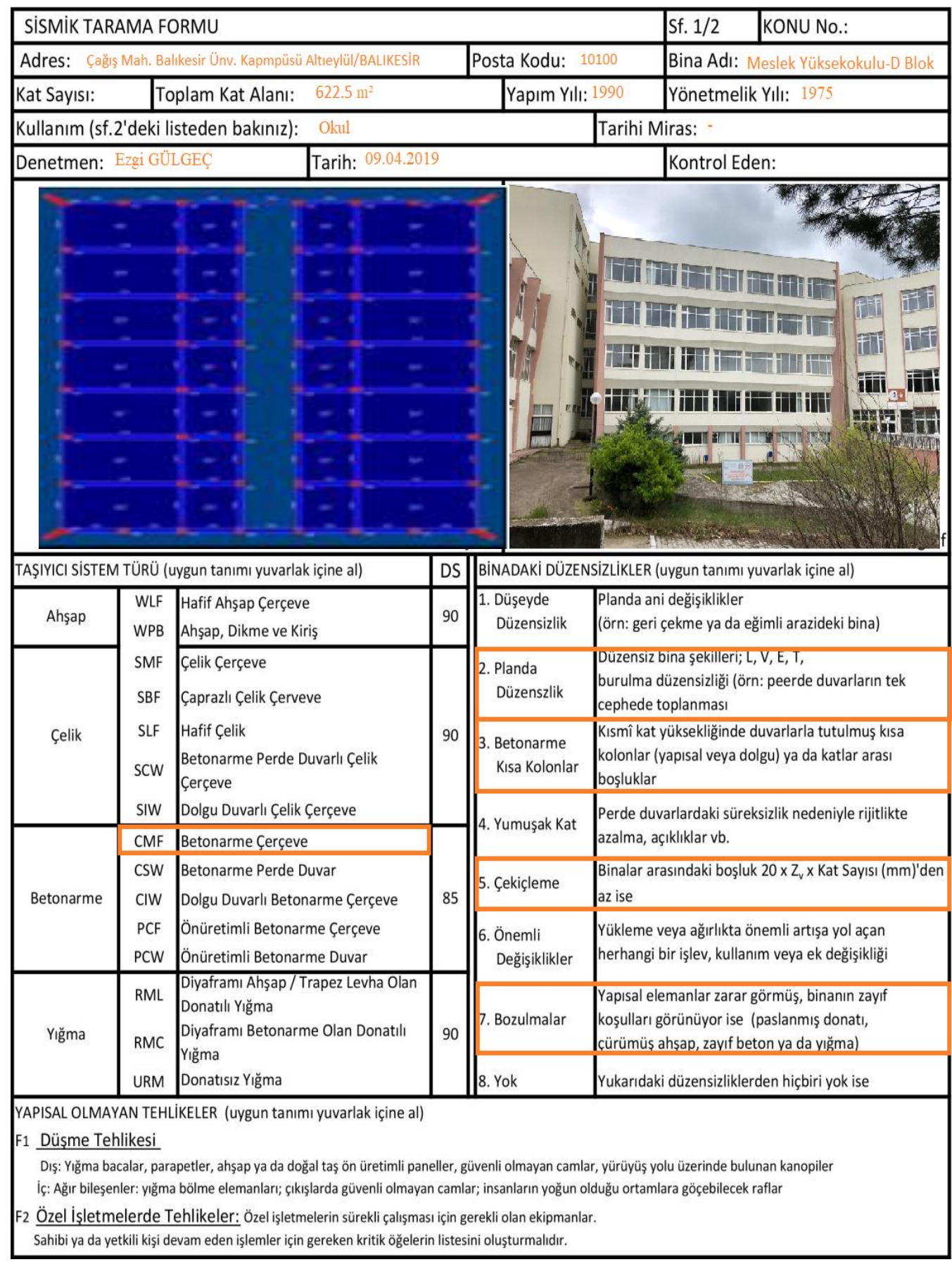

Şekil 6. Kanada sismik tarama yöntemi formu-I 


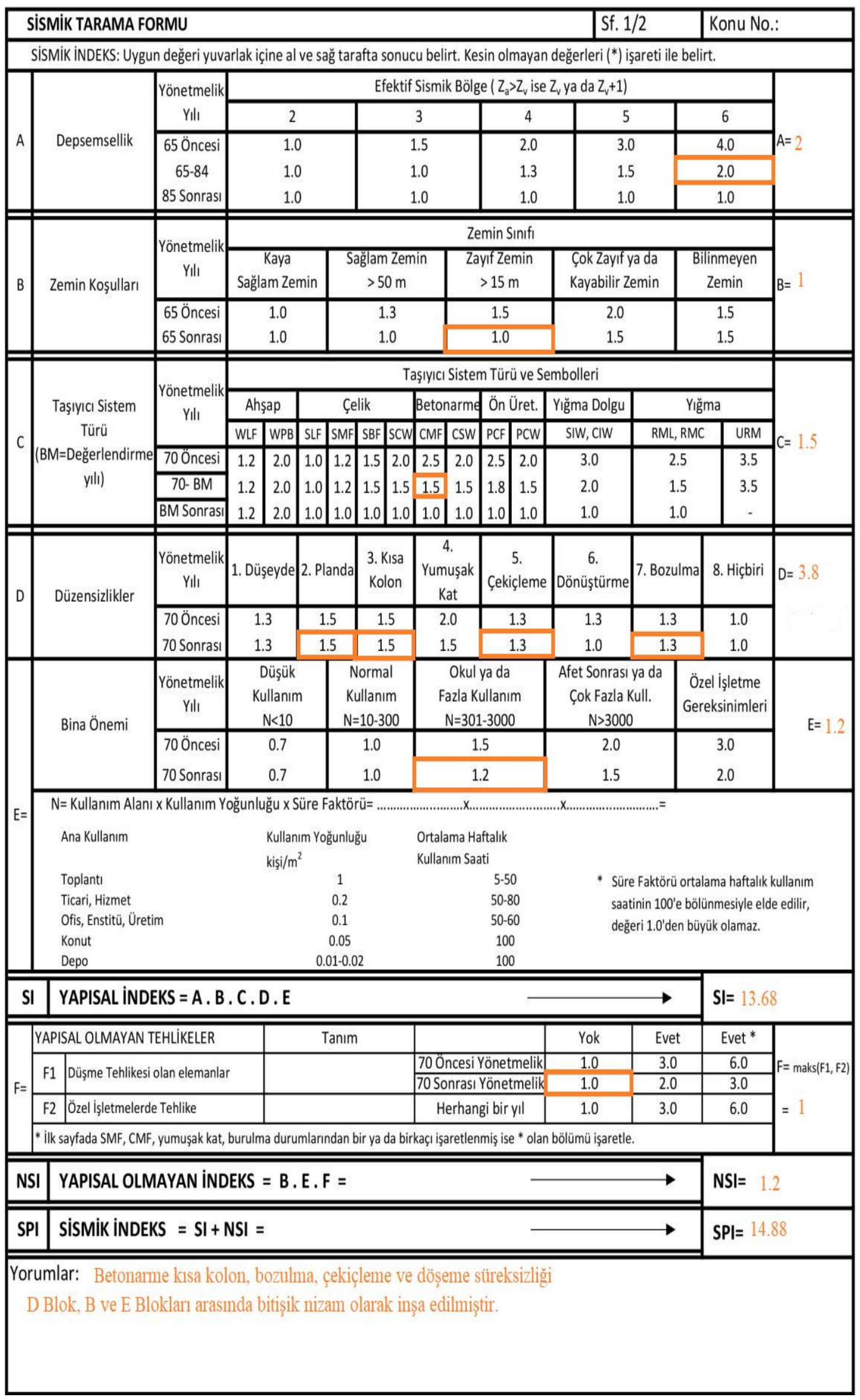

Şekil 7. Kanada sismik tarama yöntemi formu-II 


\subsection{Japon sismik indeks yöntemi}

1968 yılında Japonya'da gerçekleşen $8.3 \mathrm{M}_{\mathrm{w}}$ büyüklüğündeki Tokachi depreminin ardından önerilen Japon sismik indeks yöntemi; üç aşamalı değerlendirme yapılabilen bir hızlı değerlendirme yöntemidir[18]. Kullanıcı tercihine bağlı olarak, yöntemde ilk aşama uygulanarak, yapının deprem performansı en kaba şekli ile belirlenebilmektedir. Altı ve daha az katlı betonarme binalara uygulanabilen metotta, her kat için "Is" sismik performans indeksi ile "Iso" karşılaştırma indeksi tanımlanmakta ve bu iki indeks karşılaştırılarak yapının deprem performansı hakkında bir fikir elde edilebilmektedir. Binanın sismik performansının tespiti için hesaplanan Is "Sismik Performans indeksi" ve Iso "Sismik Karşılaştırma indeksi" karşılaştırılmaktadır. Eğer $\mathrm{I}_{S}>\mathrm{I}_{\mathrm{SO}}$ ise deprem güvenliği "yeterli", IS $<$ ISO ise yapının deprem güvenliğinin "yetersiz" olduğu sonucuna ulaşılmaktadır. Buradaki, "yeterli" ifadesi, binanın büyük bir depreme maruz kalması durumunda toptan göçme riskinin olmadığı anlamını taşımaktadır ancak hiç bir hasar almayacağı anlamına gelmemektedir[27]. Bu yöntemin ülkemizde uygulanabilirliği ile ilgili olarak Boduroğlu ve diğ. [28] tarafından yapılan çalışmada Is/Iso $\leq 0.40$ olması halinde deprem performansının yetersiz olduğu ve daha ayrıntılı incelemeler yapılması gerektiği, Is/Iso $>0.40$ olması halinde ise deprem güvenliği bakımından yeterli olduğu belirtilmiştir. Denklem 4 ile hesaplanan "Iso" karşılaştırma indeksi belirlenirken;

- Yöntemin uygulandığı aşamaya bağlı olarak belirlenen katsayı (ES),

- Yapının bulunduğu bölgenin sismik aktivitesi (Z),

- Topografik şartlar ile zeminin genel durumu (G),

- Yapının kullanım şekli ve önem derecesi (U) için seçilen değerler dikkate alınmaktadir.

$\mathrm{I}_{\mathrm{SO}}=\mathrm{E}_{\mathrm{S}} \cdot \mathrm{Z} \cdot \mathrm{G} \cdot \mathrm{U}$

Denklem 5 ile hesaplanan "IS"performans indeksi belirlenirken ise;

- Yapıda kisa kolon bulunup bulunmaması $\left(\mathrm{E}_{\mathrm{o}}\right)$,

- Yapının şekli ve fiziksel özellikleri $\left(\mathrm{S}_{\mathrm{D}}\right)$,

- Yapıda zamanla oluşan yıpranma ve etkiler (T) dikkate alınmaktadır.

$\mathrm{I}_{\mathrm{S}}=\mathrm{E}_{\mathrm{O}} \cdot \mathrm{S}_{\mathrm{D}} \cdot \mathrm{T}$

Deprem performansı araştırılan yapı için, sismik performans indeksi $I_{S}=0.000628$ ve karşılaştırma indeksi $\mathrm{I}_{\mathrm{SO}}=1.28$ olarak hesaplanmıştır. $\mathrm{I}_{\mathrm{S}}<\mathrm{I}_{\mathrm{SO}}$ olduğundan binanın deprem performansı yetersizdir. Ayrıca, Boduroğlu vd. [28] tarafından yapılan çalışmaya göre değerlendirme yapıldığında Is/Iso=0.00049 olarak hesaplanmaktadır. $0.00049<0.4$ olduğundan, bu durumda da deprem performansı yetersiz olarak teyit edilmektedir.

\subsection{P25 hızlı dĕgerlendirme yöntemi}

P25 Hizlı değerlendirme yöntemi; binaların muhtemel büyük bir depremde tamamen göçme ihtimalini belirlemek ve deprem olmadan önce kontrollü şekilde yıkılmasını ya da güçlendirilmesini sağlamak amacıyla ilk kez Bal vd. [19] tarafından P5 Metodu adı ile geliştirilmiş, daha sonra aynı araştırmacılar tarafından P24 ve son olarak P25 olmak üzere iki versiyonu yayınlanmıştır [20].

P25 metodunda, öncelikle yapının deprem sırasında en çok hasara uğrayacağı tahmin edilen katı, "kritik kat" olarak belirlenir. Yöntemde yapının teşkil edildiği zemin 
özellikleri, yapısal düzensizlikleri, malzeme özellikleri, yapı yüksekliği, mevcut düşey taşıyıcı ve dolgu duvar boyutları, rijitlikleri gibi değişkenler dikkate alınarak "P1 temel yapısal puanı" hesaplanmakta, ayrıca binaya ait farklı göçme modlarını da hesaba katan toplam yedi adet yapısal puan belirlenmektedir. Daha sonra, elde edilen puanlardan en büyük riski temsil eden en küçük puan $\left(\mathrm{P}_{\min }\right)$ belirlenerek binanın ve teşkil edildiği yörenin özelliklerine bağlı olarak bir " $\alpha$ - Düzeltme çarpanı" ile çarpılarak topografik etki de hesaba katılmış olmaktadır. Elde edilen 7 adet değerlendirme puanı ve bunların en küçüğü olan $P_{\min }$ puanının birbirleri ile etkileşim durumlarını ifade eden " $\beta$-çarpanı" elde edilmektedir. Elde edilen puanların en küçüğü olan "P $P_{\min }$, " $\alpha$ - Düzeltme çarpanı" ve " $\beta$-çarpanı" yardımıyla bir "P $P_{\text {sonuç" puanı elde edilmektedir. Hesaplanan "P }}$ sonuç" puanının daha önceden 311 bina üzerinde çalışılarak kalibre edilmesi ile belirlenen 3 farklı bölgeye düşmesi durumuna göre yapının göçme riski belirlenmekte veya daha kapsamlı bir inceleme yapılması gerektiği belirtilmektedir [9]. Bu yöntem ile elde

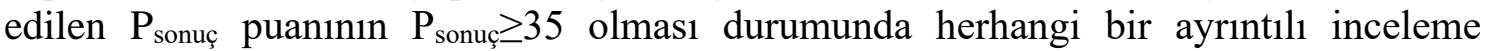
yapılması gerekmeksizin, yapının deprem performansı " "yeterli" denilmektedir. $\mathrm{P}_{\text {sonuç }}$ $35>\mathrm{P}_{\text {sonuç }}>25$ olması durumunda binanın deprem performansı hakkında net bir tahmin yapılamamakta ve yapının ayrıntılı olarak incelenmesi gerektiği ifade edilmektedir. $\mathrm{P}_{\text {sonuç }}$ puanının $\mathrm{P}_{\text {sonuç }} \leq 25$ olması durumunda yapının gerçekleşmesi muhtemel büyük bir depremde göçerek can kaybına sebep olabileceği ve güçlendirilmesi ya da yıkılarak yeniden yapılması gerektiği vurgulanmaktadır.

Deprem performansı araştırılan yapının, kalıp planı projesi üniversitenin yapı işleri daire başkanlığından alınarak taşıyıcı elemanların ve bölme duvarların konum ve boyutları kontrol edilmiş, yerinde yapılan incelemeler ile metodun uygulanabilmesi için öncelikle belirlenmesi gereken kritik kat, yapının zemin katı olarak belirlenmiştir. Yapının taban alanının içine oturtulduğu en küçük dikdörtgen belirlenerek, yapıdaki toplam 52 adet kolonun her iki yöndeki atalet momentleri, dolgu duvarların da etkisini göz önüne alarak hesaplanmıştır. İncelenen yapının bulunduğu bölgenin sismik aktivitesi, kullanım şekli, zemin ve malzeme özellikleri, düzensizlik durumları ve taşıyıcı sisteminin özellikleri de dikkate alınarak binanın deprem performansı P25 hızlı değerlendirme yöntemi ile hesaplanmış ve $\mathrm{P}_{\text {sonuç }}=15$ olarak elde edilmiştir. $\mathrm{P}_{\text {sonuç }}<25$ olduğundan binanın deprem performansı yetersizdir.

\subsubsection{P25 ÖZ-KA Revizyonu}

Betonarme binaların P25 Metodu ile değerlendirilmesi sırasında statik analizleri yapılmamakta ve dolayısıyla kat ötelemesi değerleri bilinmemektedir. Değerlendirilecek olan yapının deplasmanları ve göreli kat ötelemeleri gibi değerlendirmeyi yapacak mühendis için hayati önem taşıyan verileri de kullanmanın, P25 metodunun kapsamı ve doğruluğunu arttıracağını ifade eden Kaya ve Özkul [7,29] tarafından P25 metoduna bir revizyon önerilmiştir.

P25 ÖZ-KA revizyonunda yapının statik analizi sonucu elde edilen rölatif kat ötelemelerine bağlı olarak "Deplasman Puanı (PDEP)" belirlenmektedir. "Deplasman Puanı (P $\mathrm{P}_{\mathrm{DEP}}$ )", P25 yönteminden elde edilen sonuç puanı ile çarpılarak P25 yönteminde gri (belirsiz) bölge olarak ifade edilen bölgeyi de ortadan kaldırarak değerlendirmeyi yapan mühendisin belirli bir sonuç ortaya koymasını sağlamaktadır. Statik analiz sonucunda elde edilen rölatif kat ötelemelerine bağlı olarak belirlenen "Deplasman Puanı (P $\left.\mathrm{P}_{\mathrm{DEP}}\right)$ " ile P25 yönteminden elde edilen sonuç puanının çarpılması ile ortaya çıkan Pöz-KA sonuç puanı her zaman P25 sonuç puanına eşit ya da daha küçük çıkmaktadır. 
P25 ÖZ-KA ile elde edilen deplasman puanı, göreli kat öteleme değerlerinin $\mathrm{x}$ ve y yönlerine göre hesaplanması sonucu elde edilen elverişsiz durumun mevcut puana etki etmesi ile hesaplanmaktadır. Mevcut yapının P25 ÖZ-KA sonuç puanı (PöZ-KA); yapının statik analizi ile elde edilen hasar sınırlarına bağlı olarak, yapı Minimum Hasar Bölgesi'nde (MN) kalırsa P25 metodundan elde edilen puan ile aynı değeri alır. Statik analiz ile elde edilen hasar sınırı, Belirgin Hasar Bölgesi'nde (BH) kalırsa, yapının P25 metodundan elde edilen sonuç puanı; \%20 azaltılır. Yapı, İleri Hasar Bölgesi'nde (İH) ise \%40, Göçme Bölgesi'nde (GB) ise P25 sonuç puanı \%60 azaltılır. Dolayısıyla önerilen revizyon ile elde edilen Pöz-KA sonuç puanı, can güvenliğini sağlayacak şekilde her zaman güvenli tarafta kalmaktadır. P25 ÖZ-KA revizyonunda, belirsiz bölgenin ortadan kaldırılması için P25 yöntemindeki belirsiz bölgenin alt ve üst değerlerinin ortalaması olan 30 sınır değeri seçilmiştir. P25 ÖZ-KA revizyonu ile elde edilen PöZ-KA sonuç puanı 30 değerine eşit ya da büyük olması durumunda yapının deprem performans1, can güvenliği sağlayacak şekilde "yeterli", aksi halde "yetersiz" şeklinde net bir sonuç elde edilmektedir.

Deprem performansı araştırılan yapının, kalıp planı bir paket program ile tanımlanarak Tablo 3'te görüldüğü gibi her iki yöndeki deplasmanları hesaplanmış ve göreli kat öteleme kontrolü yapılarak her iki yöndeki hasar düzeyleri belirlenmiştir.

Tablo 3. İncelenen binanın kat deplasmanları.

\begin{tabular}{|c|c|c|c|c|}
\hline \multirow{2}{*}{ Kat no } & 9.yükleme & 10. yükleme & 11. yükleme & 12. yükleme \\
\cline { 2 - 5 } & $\boldsymbol{\delta}_{\boldsymbol{x}}(\boldsymbol{m})$ & $\boldsymbol{\delta}_{\boldsymbol{x}}(\boldsymbol{m})$ & $\boldsymbol{\delta}_{\boldsymbol{y}}(\boldsymbol{m})$ & $\boldsymbol{\delta}_{\boldsymbol{y}}(\boldsymbol{m})$ \\
\hline 3 & 0.0989981 & 0.0989981 & -0.175119 & -0.175119 \\
\hline 2 & 0.0856084 & 0.0856084 & -0.152172 & -0.152172 \\
\hline 1 & 0.0665956 & 0.0665956 & -0.117918 & -0.117918 \\
\hline $\mathrm{Z}$ & 0.0437935 & 0.0437935 & -0.078376 & -0.078376 \\
\hline $\mathrm{B}$ & 0.0193368 & 0.0193368 & -0.037090 & -0.037090 \\
\hline
\end{tabular}

Kritik kat ve kritik katın bir altındaki katın deplasmanlarının farkının kat yüksekliğine bölünmesi ve yapı davranış katsayısı "R" ile çarpılmasıyla göreli kat öteleme kontrolü yapılmış olmaktadır. Yapı davranış katsayısı $\mathrm{R}=4$ olarak belirlenmiştir. Buna göre;

$\Delta_{\mathrm{x}}=\delta_{\mathrm{x}, \text { Zemin }}-\delta_{\mathrm{x}, \text { Bodrum }}=0.0437935-0.0193368=0.0244567 \mathrm{~m}$

$\Delta_{\mathrm{y}}=\delta_{\mathrm{y}, \text { Zemin }}-\delta_{\mathrm{y}, \text { Bodrum }}=0.078376-0.037090=0.041286 \mathrm{~m}$

Göreli Kat Öteleme Kontrolü (x) ; R x $\Delta_{\mathrm{x}} / \mathrm{h}=4$ x $0.0244567 / 3.80=0.025744$

Göreli Kat Öteleme Kontrolü (y) ; R x $\Delta_{\mathrm{x}} / \mathrm{h}=4$ x 0.041286 / $3.80=0.043459$

olarak hesaplanır.

Hesaplanan x ve y doğrultusundaki göreli kat öteleme kontrolü değerleri, Tablo 4'de belirtilen sınırlara bağlı olarak hasar bölgeleri tespit edilir.

Tablo 4. P25 ÖZ-KA Deplasman puanı için P25 yöntemi sonuç puanına etkitilen deplasman katsayıları. 


\begin{tabular}{|c|c|c|c|c|}
\hline \multirow[b]{2}{*}{$\begin{array}{c}\text { P25 ÖZ-KA } \\
\text { Puanı }\end{array}$} & \multicolumn{4}{|c|}{ Hasar Bölgeleri } \\
\hline & $\mathrm{MN}<0.01$ & $0.01<$ BH $<0.03$ & $0.03<\dot{\mathbf{I} H}<0.04$ & $0.04<G B$ \\
\hline $\begin{array}{l}\mathrm{x} \text { yönünde } \\
\text { P DEP }\end{array}$ & $\mathrm{P} 25_{\text {sonuç }}$ & $\mathrm{P} 25_{\text {sonuç }} \times 0.80$ & $\mathrm{P} 25_{\text {sonuç }}$ x 0.60 & $\mathrm{P} 25_{\text {sonuç }} \mathrm{x} 0.40$ \\
\hline $\begin{array}{c}\text { y yönünde } \\
\text { P }_{\text {DEP }}\end{array}$ & $\mathrm{P} 25_{\text {sonuç }}$ & $\mathrm{P} 25_{\text {sonuç }} \mathrm{x} 0.80$ & $\mathrm{P} 25_{\text {sonuç }} \times 0.60$ & $\mathrm{P} 25_{\text {sonuç }} \mathrm{x} 0.40$ \\
\hline
\end{tabular}

MN : Minimum Hasar Bölgesinde kalan göreli kat öteleme değeri

BH : Belirgin Hasar Bölgesinde kalan göreli kat öteleme değeri

İH : İleri Hasar Bölgesinde kalan göreli kat öteleme değeri

GB : Göçme Bölgesinde kalan göreli kat öteleme değeri

Göreli Kat Öteleme Kontrolü (x); $\quad 0.01<0.025744<0.03$

Göreli Kat Öteleme Kontrolü (y); $\quad 0.04<0.043459$

Yapının x yönüne göre elde edilen hasar düzeyi "Belirgin Hasar Bölgesinde", y yönüne göre ise "Göçme Bölgesinde" kaldığından P25 Yöntemi sonuç puanı \%60 azaltılarak P25 ÖZ-KA sonuç puanı $\mathrm{P}_{\text {ÖZKA }}=6$ olarak hesaplanmıştır. $\mathrm{P}_{\text {ÖZ-KA }}<30$ olduğundan binanın deprem performansı yetersizdir.

\section{Sonuçlar}

Yapılan çalışma ile Balıkesir'de daha önceden ayrıntılı deprem performansı araştırılarak belirlenen bir okul binasının 4 farklı ve 1 revize edilmiş metot kullanılarak hızlı değerlendirmesi yapılmıştır. Yapılan hızlı değerlendirmelerin her birinden elde edilen sonuçlar ve ayrıntılı inceleme sonucunda belirtilen nihai sonuç; binanın deprem performans düzeyinin "yetersiz" olduğu şeklindedir.

FEMA 154 Sismik Tarama Yöntemi, diğer yöntemlere göre daha basit ve uygulamas1 en kolay metottur. Uygulama süresi oldukça kısa olması sebebiyle hızlı değerlendirme yapılması düşünülen bölgedeki yapı stoku hakkında genel bir fikir edinilmesi amacıyla kullanılabilir ancak yöntemin değerlendirmeye aldığı parametrelerin oldukça kısıtlı olmas1, yöntemin güvenilirliği açısından olumsuz bir faktör olarak ön plana çıkmaktadır.

Kanada Sismik Tarama Yöntemi de, FEMA 154 yöntemine benzer şekilde tek bir form ile uygulanabilen, görece basit ve kısa sürede tamamlanabilen bir metottur. FEMA 154 yönteminde olduğu gibi yapı stoku hakkında fikir edinmek amacıyla belirli bir bölgeye uygulanabilir. Yöntemin değerlendirmeye aldığı parametreler FEMA 154 yöntemine göre daha kapsamlı olmasına rağmen yeterli düzeyde olduğunu ifade etmek oldukça zordur. Ayrıca yöntem, Kanada'da yayınlanan yönetmelik şartları ve yıllarına bağlı olarak hazırlanmıştır; yöntemin uygulanması sırasında kendi ülkemizdeki yönetmelik şartları ve yıllarını göz önüne alarak değerlendirme yapmak, başka bir deyişle ülkemiz koşullarına adapte etmek gerekmektedir. Kanada sismik indeks metodunda, örneğin "A" parametresi ile temsil edilen "Depremsellik Faktörü" 1985 yılından sonra Kanada'da yapılan yapıların tamamında yapı-zemin etkileşiminin yarattığ tehlike 
düzeyini düşük kabul ederek her durum için "1.0" olarak almakta, dolayısıyla yapının risk seviyesini düşürmektedir. Oysa ülkemizdeki yap1 stokunun tamamına, yapının teşkil edildiği günün yönetmelik şartlarının uygulandığını ifade etmek mümkün olmadığı için, 1998 yılı yönetmeliği şartları ile teşkil edilmiş yapılarda bile risk seviyesini bu kadar düşürmek mümkün değildir. Bu durum diğer parametreler için de geçerlidir. Tüm bu faktörler göz önüne alındığında yöntemin güvenilirliği diğerlerine göre daha düşüktür.

Japon Sismik İndeks Yöntemi, 3 aşamalı bir değerlendirme yöntemidir. Sunulan çalışmada ilk aşama değerlendirme sonuçlarına yer verilmiştir. FEMA 154 ve Kanada sismik indeks metodunda olduğu gibi belirli bir bölgedeki binaların tamamına hızlı şekilde uygulanabilecek bir metot olmasına karşılık ilk değerlendirme aşaması için bile FEMA 154 ve Kanada sismik indeks yöntemlerine göre göz önüne alınan parametreler daha kapsamlıdır. Boduroğlu vd. [28] tarafından yapılan çalışma ile yöntemin sonucunun kendi içerisinde kıyaslanması, yöntemin güvenilirliğinin de artmasını sağlamıştır.

P25 Hızlı Değerlendirme Yöntemi, birçok parametre dikkate alınarak uygulanan, önceki depremlerde tamamen yıkılmış binalara uygulanarak kalibre edilmiş, ülkemiz araştırmacıları tarafindan geliştirilmiş, uzun yıllardır birçok araştırmacı tarafından yüzlerce binaya uygulanmış bir metot olması dolayısıyla güvenilirlik açısından ön plana çıkmaktadır. Uygulamasının nispeten daha uzun sürmesi sebebiyle yöntemin belirli bir bölgeye uygulanmasından ziyade bir tek binanın deprem performansının hızlı şekilde değerlendirmesi açısından uygun olduğu düşünülmektedir. Kaya ve Özkul [7,29] tarafından önerilen revizyon ile uygulama süresi bir miktar artmasına karşılık binanın günümüz şartlarında hızlı ve basit şekilde bir bilgisayar programı ile tanımlanabileceği de göz önüne alınarak, yapının deplasmanları ve kat ötelemeleri gibi uygulamayı yapacak olan mühendis için hayati öneme sahip verilerin de yönteme eklenmesi ile metodun güvenilirliğinin arttırdığı düşünülmektedir.

Sonuç olarak, hızlı değerlendirme metotları arasında en doğru ya da en yanlış metot şeklinde bir değerlendirme yapmak yerine incelenecek yapı grubu için "en uygun" yöntemin belirlenmesi doğru bir yaklaşım olacaktır. Türkiye Cumhuriyeti gibi topraklarının büyük bölümü deprem tehlikesi altında olan ve bu depremlerden de tarihi boyunca çok büyük yaralar almış bir ülkenin yaşanılan her depremden sonra yıkıntıları kaldırarak, "orada kimse var mı?" diye sormak yerine hangisi olursa olsun, bir an önce bir yöntem belirleyerek işe başlaması elzemdir. Ülkemizdeki mevcut yapı stokunun çok hızlı şekilde değerlendirilmeye alınması, göçme riski tespit edilen yapıların acil olarak boşaltılarak oluşabilecek muhtemel can kayıplarının önüne geçilmesi, tarihi değeri olan yapıların restore edilerek güçlendirilmesi, tarihi değeri olmayan yapıların maliyete bağlı olarak güçlendirilmesi ya da yıkılıp yeniden yapılması gerekmektedir. Aksi halde ülkemizde daha önce defalarca yaşadığımız felaketlerin bir benzerinin yeniden yaşanması kaçınılmaz olacaktır.

\section{Teşekkür}

Bu çalışma, Balıkesir Üniversitesi tarafından 2017/070 numaralı Bilimsel Araştırma Projesi ile desteklenmiştir. 


\section{Kaynaklar}

[1] Özkul, B. ve Karaman A.E., Doğal afetler için risk yönetimi, TMMOB İnşaat Mühendisleri Odası, Afet Sempozyumu, Ankara, 251-261, 5-7 Aralık, 2007.

[2] Kılıç, B., Betonarme yapıların deprem güvenliğinin hızlı değerlendirilmesi ve Balıkesir uygulaması, Yüksek Lisans Tezi, Balıkesir Üniversitesi, Fen Bilimleri Enstitüsü, Balıkesir, (2014).

[3] Tural, M., Betonarme yapıların deprem güvenliklerinin hızlı değerlendirme yöntemleri ile karşılaştırılması, Yüksek Lisans Tezi, Gebze Yüksek Teknoloji Enstitüsü Mühendislik ve Fen Bilimleri Enstitüsü, Gebze, (2014).

[4] Özkaratay, M., Düzce depreminde yıkılmış 6 katlı betonarme binanın farklı yöntemlerle değerlendirilmesi, Yüksek Lisans Tezi, İstanbul Teknik Üniversitesi, Fen Bilimleri Enstitüsü, İstanbul, (2014).

[5] Bütün, D., Betonarme yapıların göçme risklerinin belirlenmesinde kullanılan hızlı yöntemlerin karşılaştırılması, Yüksek Lisans Tezi, Celal Bayar Üniversitesi, Fen Bilimleri Enstitüsü, Manisa, (2018).

[6] Kızılkaya, B. Ş.,FEMA 154 Hızlı görsel tarama, Kanada sismik tarama ve Japon sismik indeks yöntemlerinin karşılaştırmalı değerlendirmesi ve uygulaması, Yüksek Lisans Tezi, İstanbul Teknik Üniversitesi, Fen Bilimleri Enstitüsü, İstanbul, (2018).

[7] Kaya, A., Mevcut betonarme konut tipi binaların deprem performanslarının hızlı değerlendirme metotları ile incelenmesi ve P25 metodunun geliştirilmesi, Yüksek Lisans Tezi, Balıkesir Üniversitesi, Fen Bilimleri Enstitüsü, İnşaat Mühendisliği Anabilim Dalı, Balıkesir, (2017).

[8] Efekan, S., Yapıların deprem performansının hızlı değerlendirme yöntemleri ile belirlenmesi ve sonuçların karşılaştırılması, Yüksek Lisans Tezi, Maltepe Üniversitesi, Fen Bilimleri Enstitüsü, İstanbul, (2019).

[9] Işık, E. ve Kutanis M., Bitlis ilindeki betonarme binaların P25 hılı tarama yöntemi ile değerlendirilmesi, BAUN Fen Bil. Enst. Dergisi, 15,1, 21-29, (2013).

[10] Uğur, O.U., Aliefendioğlu, Y. ve Saka, M., Afet riski altındaki alanların dönüştürülmesi hakkında kanuna göre riskli yap1 tespitinde karşılaşılan uygulama problemlerinin vaka tabanlı incelenmesi: Tekirdağ ili örneği, Düzce Üniversitesi Bilim ve Teknoloji Dergisi, 4, 354-375, (2016).

[11] Işık E., Bozkurt N. ve Taşkın V., Muş ili yapı stoğunun kanada sismik tarama yöntemi ile incelenmesi ve bölgenin depremselliği, Süleyman Demirel Üniversitesi Fen Bilimleri Enstitüsü Dergisi, 21,2, 421-429, (2016).

[12] Gürbüz, A. ve Tekin, M., Farklı tip betonarme binalar için geliştirilmiş hasar tahmin yöntemleri, İMO Teknik Dergi, 28, 4, 8051-8076, (2017).

[13] Türkel Y.E. ve Tekeli H., Konut türü betonarme binaların deprem risk değerlendirmesi, Politeknik Dergisi, 21, 3, 669-680, (2018).

[14] Kepenek E., Korkmaz K. A. ve Gencel Z., Seismic risk investigation for reinforced concrete buildings in Antalya, Turkey, Computers and Concrete, 26, 3, 203-211, (2020).

[15] Erşahan, Ö.A., Köse, M.M. ve Avğın, S., P25 Metodu ile Kahramanmaraş yapı stoğunun incelenmesi, KSÜ Mühendislik Bilimleri Dergisi, 23, 1, 9-21, (2020).

[16] FEMA 154 - ATC-21: Rapid visual screening of buildings for potential seismic hazards: a handbook. Applied Technology Council. Federal Emergency Management Agency. Washington DC, (1988). 
[17] NRRC. Manual for Screening of Buildings for Seismic Investigation. Canadian Standard. Ottowa: National Research Council of Canada, (1993).

[18] JBDPA, Standard for Seismic Evaluation of Existing Reinforced Concrete Buildings, The Japan Building Disaster Prevention Association, Tokyo, (2001).

[19] Bal İ. E., Deprem etkisindeki betonarme binaların göçme riskinin hızlı değerlendirme yöntemleri ile belirlenmesi, Yüksek Lisans Tezi, İstanbul Teknik Üniversitesi, Fen Bilimleri Enstitüsü, İstanbul, (2005).

[20] Bal, İ.E., Tezcan, S. S. ve Gülay, F. G., Betonarme binaların göçme riskinin belirlenmesi için P25 hızlı değerlendirme yöntemi, Altıncı Ulusal Deprem Mühendisliği Konferansı, 661-673, İstanbul, (2007).

[21] Gülen, A., R., Deprem risk analizi ve şehirleşmede Balıkesir kent merkezi örneği, Yüksek Lisans Tezi, Balıkesir Üniversitesi, Fen Bilimleri Enstitüsü, Balıkesir, (2008).

[22] Yazıcı, N., Ocak 1898 Balıkesir depremi ve sonrası, Ankara, (2003).

[23] Sözbilir H., Özkaymak Ç., Sümer Ö., Uzel B. ve Eski S., Balıkesir ilinin deprem tehlike kaynakları ve alınması gereken önlemler, Balıkesir'in Afet Durumu ve Yönetimi Çalıştayı, Balıkesir, (2019).

[24] Mikyas Grup Mühendislik, Balıkesir Üniversitesi, Meslek Yüksekokulu Deprem Performansı Değerlendirme Raporu, (2017).

[25] Özkul, B. Ve Gülgeç E., Betonarme yapıların deprem performanslarının belirlenmesi için kullanılan hızlı değerlendirme metotlarının karşılaştırılması, Balıkesir Üniversitesi, Araştırma Projesi (2017/70), (2019).

[26] Gülgeç, E., Betonarme yapıların deprem performanslarının belirlenmesi için kullanılan hızlı değerlendirme metotlarının karşılaştırılması, Yüksek Lisans Tezi, Balıkesir Üniversitesi, Fen Bilimleri Enstitüsü, (2019).

[27] Kasımzade, A., A., Karaca Z. ve Sönmez B., Ön sismik değerlendirmede Japon Sismik İndeks Yönteminin lise binalarında uygulanması özellikleri, Kocaeli Deprem Sempozyumu, 464-474, Kocaeli, (2005).

[28] Boduroğlu, H., M., Özdemir, P., İlki, A., Sirin, S., Demir, C., ve Baysan, F., Towards a modified rapid screening method for existing medium rise RC buildings in Turkey, 13th World Conference on Eartquake Engineering, Paper No.1542, Vancouver, B.C., Canada, (2004).

[29] Kaya A. ve Özkul B., Balıkesir ilinde bulunan mevcut betonarme binaların hızlı değerlendirme metotları ile değerlendirilmesi ve P25 metodunun geliştirilmesi, Balıkesir 2. Kent Sempozyumu, (2015) 